\title{
Srednjovjekovni bosansko-humski vladari i velmože u hodonimima Hercegovine
}

Dijana Korać

Sveučilište u Mostaru, Filozofski fakultet

University of Mostar

Faculty of Humanities and Social

Sciences

E-mail: dijana.korac@ff.sum.ba

Marina Beus

Sveučilište u Mostaru, Filozofski fakultet

University of Mostar

Faculty of Humanities and Social

Sciences

E-mail: marina.beus@ff.sum.ba
UDK: 930.85(497.6)"04/14"

Prethodno priopćenje

Primljeno: 18. ožujka 2021.

Prihvaćeno: 29. lipnja 2021.

\section{Sažetak}

Analiza prisutnosti srednjovjekovnih bosansko-humskih vladara i velmoža u najnovijoj uličnoj nomenklaturi na području dvije hercegovačke županije (Hercegovačko-neretvanska i Zapadno-hercegovačka) pokazala je njihovu zastupljenost u gradovima i općinama s većinskim hrvatskim stanovništvom. Naime, u osam hercegovačkih gradova i općina nalazi se 28 hodonima koji komemoriraju uspomenu na 11 srednjovjekovnih bosanskohumskih vladara i velmoža. Na kraju, ti se rezultati uspoređuju s onima koji se odnose na prisutnost srednjovjekovnih hrvatskih vladara u uličnoj toponimiji Hercegovine.

Ključne riječi: bosansko-humski vladari i velmože; Hercegovina; hodonimi; ulice; trgovi. 


\title{
Medieval Bosnia-Hum rulers and potentates in the odonyms of Herzegovina
}

\author{
Preliminary communication \\ Received: 18 March 2021 \\ Accepted: 29 June 2021
}

\section{Summary}

The paper analyses presence of medieval Bosnia-Hum rulers and potentates in the latest street nomenclature in the area of two Herzegovinian cantons (Herzegovina-Neretva and West Herzegovina). The street nomenclature analysis showed that eleven Bosnia-Hum rulers and potentates were represented in the cities and municipalities with Croatian majority population. Comparing the obtained data to results of the research related to the presence of the medieval Croatian rulers in the odonyms of Herzegovina, the authors came to the conclusion that medieval Croatian rulers are more significantly represented in the Herzegovinian toponymy than Bosnia-Hum rulers and potentates.

Keywords: Bosnia-Hum rulers and potentates; Herzegovina; odonyms; streets; squares.

\section{Uvod}

Ulična nomenklatura zbog svoje složene simbolike, koja s jedne strane podrazumijeva kreiranje prostorne identifikacije, dok $s$ druge strane, kroz "nenametljivo" ali svakodnevno podsjećanje na odabrane osobe, značajne datume, mjesta, čini važnu kariku u konstruiranju kulturnoga identiteta, posljednjih je desetljeća predmet interesa interdisciplinarnih i multidisciplinarnih istraživanja. Poseban interes znanstvenika svakako pobuđuju društveno-političke prijelomnice kao što je u novijoj hrvatskoj povijesti slom komunizma i dolazak 
demokratski izabrane vlasti. ${ }^{1}$ Međutim, valja naglasiti kako ulična nomenklatura, kao sustav simbola koji ima cilj kreirati i jačati kolektivni identitet ${ }^{2}$ temeljen na kulturi sjećanja po mjeri društveno-

1 Interes za ovu problematiku unutar hrvatskoga akademskog diskursa potaknula je krajem devedesetih godina prošloga stoljeća etnologinja Dunja Rihtman-Auguštin u svom djelu: Ulice moga grada. Antropologija domaćeg terena, Beograd, 2000. Ovdje također navodimo neke od radova koji se bave ovom tematikom: Borislav Grgin, "Primjer selektivnog pamćenja: hrvatski srednjovjekovni vladari u nazivlju ulica i trgova najvažnijih hrvatskih gradova", u: Povijesni prilo$z i$, 32, Zagreb, 2007., str. 283-295; Zlatko Begonja, "Odonimi kao ideološke manifestacije na primjeru Zadra u XX. stoljeću", u: Radovi Zavoda za povijesne znanosti HAZU u Zadru, 48, Zadar, 2006., str. 703-720; ZDRAVKA JELASKA MARIJAN, "Službena imenovanja i preimenovanja ulica u Splitu 1912.-1928. godine", u: Studia ethnologica Croatica, 26, Zagreb, 2014., str. 229-252; IvANA CrLJEnko, "Izraženost identiteta u gradskoj toponimiji kvarnerskih i istarskih gradova", u: Hrvatski geografski glasnik, Zagreb, 1/2008., str. 67-89; JELENA STANIĆ - LAURA ŠAKaJA - LANA SlavuJ, "Preimenovanja zagrebačkih ulica i trgova", u: Migracijske i etničke teme, Zagreb, 1-2/2009., str. 89-124; LenA MirošEvić, "Imena ulica i trgova kao odraz zajedničkoga kulturno-povijesnog naslijeđa", u: Kartografija i geoinformacije, 16, Zagreb, 2011., str. 57-71; BojAn MarJanović, "Promjena vlasti, promjena ulica", u: Diskrepancija, 12, Zagreb, 2007., str. 105-127; LENA MirošEvić - MARIN Borzić, "Ulična nomenklatura grada Splita kao odraz političkih i kulturnih promjena", u: Etnološka tribina: Godišnjak Hrvatskog etnološkog društva, 37, Zagreb, 2014., str. 187-201; Ivica MataijA, "Gospićka hodonimija", u: Folia onomastica Croatica, 23, Zagreb, 2014., str. 143-158. U navedenim radovima može se vidjeti pregled stranih autora i njihovih djela koji donose rezultate istraživanja ove tematike u različitim zemljama.

2 Duško Petrović, "Anatomija identiteta. Teorijsko problematiziranje identiteta", u: Etnološka istraživanja, 11, Zagreb, 2006., str. 226-227; I. CRLJENKO, "Izraženost identiteta u gradskoj toponimiji kvarnerskih i istarskih gradova", str. 69; L. MirošEvić, "Imena ulica i trgova kao odraz zajedničkoga kulturno-povijesnog naslijeđa", str. 69; Lena MirošEvić, "Gradska toponimija kao nositelj kolektivnih identiteta", u: Vladimir Skračić - Josip FARIČIĆ (ur.), Geografska imena. Zbornik radova s Prvog nacionalnog znanstvenog savjetovanja o geografskim imenima, Zadar, 2011., str. 83-93; J. STANIĆ - L. ŠAKAJA - L. Slavuj, "Preimenovanja zagrebačkih ulica i trgova", str. 90; B. Marjanović, "Promjena vlasti, promjena ulica", str. 109; B. GrGIN, "Primjer selektivnog pamćenja: hrvatski srednjovjekovni vladari u nazivlju ulica i trgova najvažnijih hrvatskih gradova", str. 283-295; Z. BEgonjA, "Odonimi kao ideološke manifestacije na primjeru Zadra u XX. stoljeću", str. 719; Eric HobsBAWM, "Izmišljanje tradicije", u: Maja Brkljačić - SANdra Prlenda (prir.), Kultura pamćenja $i$ historija, Zagreb, 2006., str. 139. Više relevantnih radova vezanih uz tematiku kolektivnoga sjećanja i pamćenja vidjeti u zbornicima radova: Maja Brkljačić - SANdra Prlenda (prir.), Kultura pamćenja i historija, Zagreb, 2006.; Michal Sladeček - Jelena Vasiljević - Tamara Petrović, Kolektivno sećanje i politike pamćenja, Beograd, 2015. 
političkih elita, ima dugu tradiciju i poklapa se s razvitkom nacija odnosno uspostavom nacionalnih država. ${ }^{3}$ Iako je, uglavnom, prva asocijacija na nazivlje ulica i trgova lakša orijentacija ljudi u određenu prostoru, kao što smo već naglasili, hodonimi s vremenom dobivaju puno dublje simboličko značenje postajući važan čimbenik ideologiziranja svakodnevnoga života. Stoga svaka velika društvenopolitička i povijesna promjena manifestira se i na izmjeni ulične nomenklature koja se "nikad ne konstituira i ne mijenja spontano nego je u pravilu ovisna o političkim ideologijama i političkoj moći", ${ }^{4}$ koje se nedvojbeno oslanjaju na ulogu i važnost kulturno-povijesnoga nasljeđa u jačanju kolektivnoga identiteta, te važnost povijesti i kolektivnoga sjećanja, pri čemu treba imati na umu da se gotovo uvijek radi o selektivnom sjećanju. Ova praksa uočava se i na primjeru Hercegovine, koja je tijekom 20. stoljeća bila u sastavu različitih država, pa se i ulična onomastika mijenjala u skladu s promjenama sustava državne vlasti. U središtu pozornosti ovoga istraživanja je razdoblje postsocijalističke transformacije uvjetovane raspadom bivše jugoslavenske države i nastankom samostalne Bosne i Hercegovine kada dolazi do značajne izmjene u nomenklaturi kako različitih institucija, tako i ulica i trgova. Ovaj proces popraćen je uklanjanjem jugoslavensko-socijalističkog okvira, kroz odbacivanje simbola i osoba koji podsjećaju na ranije društveno-političko razdoblje, te uspostavom novih nacionalnih narativa uzrokovanih identitetsko-političkim zaokretom. U hercegovačkoj onomastici ovoga razdoblja svoje mjesto našli su i srednjovjekovni bosansko-humski vladari i velmože što je suvremenim kreatorima hercegovačke društveno-političke zbilje trebalo poslužiti kao kulturno-povijesni segment u jačanju nacionalne svijesti i kolektivnog identiteta. ${ }^{5}$

3 SRĐAn Radović, "Politike simbola na gradskim ulicama: obrasci preimenovanja javnih prostora u postjugoslovenskim zemljama", u: Narodna umjetnost: hrvatski časopis za etnologiju i folkloristiku, Zagreb, 2/2014., str. 119.

4 D. Rintman-Auguštin, Ulice moga grada. Antropologija domaćeg terena, str. 48-49; S. RAdović, "Politike simbola na gradskim ulicama: obrasci preimenovanja javnih prostora u postjugoslovenskim zemljama", str. 119.

$5 \mathrm{Na}$ ovakve izmjene hodonima svakako je utjecala i nacionalna svijest, koja prema istraživanju nekih autora, posebno dolazi do izražaja nakon ratova i jačanja zajedničkog identiteta. O tome: BorIs BANOvaC, "Etničnost i regionalizam u Istri: povijesni rakurs i suvremeni kontekst", u: Migracijske i etničke teme, Zagreb, 4/1996., str. 279; Boris BANOvaC, "Modernitet, prostor i konstrukcija identiteta", u: Revija za sociologiju, Zagreb, 3-4/2000., str. 114; DušKo SEkulić, "Prostor i identitet", u: Erasmus, časopis za kulturu demokracije, 
U radu se analizira prisutnost ovih hodonima u Hercegovačko-neretvanskoj i Zapadno-hercegovačkoj županiji. ${ }^{6}$ Analiza se temelji na podatcima iz službenih glasnika te web stranica gradova i općina, ${ }^{7}$

19, Zagreb, 1997., str. 46-57. Treba naglasiti kako je u gradovima i općinama u kojima nema mnogo Hrvata, ulična onomastika bitno drugačija, a izmjene nazivlja u odnosu na raniji društveno-politički sustav znatno su manje.

6 U ovim županijama nalazi se 13 gradova i općina (Mostar, Čapljina, Široki Brijeg, Ljubuški, Čitluk, Stolac, Ravno, Neum, Grude, Posušje, Prozor-Rama, Jablanica i Konjic).

7 Rezultati analize uličnoga nazivlja izneseni u tekstu, tabelama i grafikonima ovoga rada temelje se na podatcima objavljenim u: Službeno glasilo Općinskog vijeća općine Mostar, Mostar, 1-2/1995., str. 10; Službeno glasilo Općinskog vijeća općine Mostar, Mostar, 5/1995., str. 16; Službeno glasilo općina Zapad, Jugozapad i Jug Mostar, Mostar, 3/1998., str. 11; Službeno glasilo gradske općine Mostar Jugozapad, Mostar, 3/2003., str. 1; Službeno glasilo Općinskog vijeća općine Čitluk, Čitluk, 8/2013., str. 139-141; Službeno glasilo Općinskog vijeća općine Čitluk, Čitluk, 5/2015., str. 85-87; Službeno glasilo Općinskog vijeća općine Čitluk, Čitluk, 2/2016., str. 63; Službeno glasilo Općinskog vijeća općine Čitluk, Čitluk, 4/2016., str. 97; Službeno glasilo Općinskog vijeća općine Citluk, Čitluk, 4/2019., str. 47; Službeno glasilo Općinskog vijeća općine Čitluk, Čitluk, 7/2020., str. 57-58; Službeni glasnik općine Posušje, Posušje, 1/2005., str. 1-8; Službeni glasnik općine Posušje, Posušje, 5/2005., str. 203; Službeni glasnik općine Posušje, Posušje, 10/2005., str. 89; Službeni glasnik općine Posušje, Posušje, 12/2018., str. 215-216; Službeni glasnik općine Široki Brijeg, Široki Brijeg, 1/2004., str. 24-42; Službeni glasnik grada Širokog Brijega, Siroki Brijeg, 6/2015., str. 194; Službeni glasnik općine Ljubuški, Ljubuški, 1/2016.; Službeni glasnik općine Ljubuški, Ljubuški, 7/2017., str. 322-325; Narodni list općine Neum, Neum, 1/1993., str. 3-4; Rješenje o utvrđivanju novih imena ulica u Neumu, br. Rješenja R-01-I-13/02, Neum, 27. ožujka 2002.; Odluka o adresnom sustavu općine Neum i označavanju naseljenih mjesta, ulica i trgova nazivima te zgrada brojevima, broj Odluke 01-02-870/17, Neum, 19. 6. 2017.; Narodni list općine Čapljina. Službeno glasilo, Čapljina, 2/2016., str. 1-3; Narodni list općine Stolac, Stolac, 3/1994., str. 2-3; Odluka o obilježavanju ulica, parka i trga imenima i zgrada brojevima na području općine Grude, br. Odluke 01-23-250/04, Grude, 22. lipnja 2004.; https://prozor-rama.org/o-opcini (8. 1. 2021.); https:// ravno.ba/ (8. 1. 2021.); http://jablanica.ba/20/o-opcini/ulice-naseljena-mjestajablanica.html, Odluka o nazivima dijelova naseljenih mjesta i ulica i njihovom obilježavanju, broj Odluke 02-02-845-7/05-VII, Jablanica, (9. 6. 2005.); http:// www.kartabih.com/karta-konjic/ (8. 1. 2021.). Napominjemo da smo tijekom istraživanja ove problematike i prikupljanja potrebite građe iz mjerodavnih općinskih tijela vlasti u općini Ravno i općini Prozor-Rama došli do podataka da, iako se na službenim stranicama i jedne i druge općine, te u službenim općinskim aktima koriste, u odnosu na razdoblje komunizma, novi nazivi ulica, odnosno trga kada je riječ o općini Ravno, njihovo imenovanje nije, do zaključivanja ovoga rada, prošlo pravnu proceduru. Također treba naglasiti, da u 
Dijana Korać - Marina Beus - Srednjovjekovni bosansko-humski vladari i velmože...

iz kojih je evidentno da se u uličnoj nomenklaturi osam hercegovačkih gradova i općina komemorira uspomena na jedanaest srednjovjekovnih bosansko-humskih vladara i velmoža. Dobiveni podatci o učestalosti pojave ovih hodonima uspoređuju se s rezultatima do kojih se došlo ranijom analizom prisutnosti srednjovjekovnih hrvatskih vladara u ovim županijama. ${ }^{8}$

\section{Rezultati istraživanja}

Uvidom u ulično nazivlje Hercegovine uočava se kako su srednjovjekovni bosansko-humski vladari i velmože zastupljeni u gradovima i općinama s hrvatskim većinskim stanovništvom. ${ }^{9}$ Naime, u uličnoj nomenklaturi osam hercegovačkih gradova i općina (Mostar, Široki Brijeg, Posušje, Čapljina, Ljubuški, Citluk, Stolac i Neum) na području dvije spomenute županije nalazimo jedan trg i 27 ulica u kojima je komemorirano jedanaest srednjovjekovnih bosansko-humskih vladara i velmoža. S druge strane, u Konjicu i Jablanici (većinsko bošnjačko stanovništvo) ne nalazimo nijednu ulicu i trg koja komemorira njihovo ime. Spomenimo i to da na području Hercegovine u gradovima i općinama koje pripadaju Republici Srpskoj postoji nekoliko ovakvih hodonima (primjerice u Trebinju - Ulica hercega Stefana Kosače i Vojvode Vlatka Vukovića, ${ }^{10}$ ili pak ulica Hercega Stefana u Gacku ${ }^{11}$ ).

S obzirom na geografsku distribuciju, analiza uličnoga nazivlja u kojemu su komemorirana imena srednjovjekovnih bosansko-humskih vladara i velmoža pokazuje da je na prvome mjestu Posušje s osam ovakvih hodonima (29\%). Na drugome mjestu nalazi se Široki Brijeg sa šest imenovanih ulica, odnosno $21 \%$ od ukupna broja u navedenim hercegovačkim gradovima i općinama. Treće mjesto dijele Mostar i Čitluk u kojima po tri ulice nose imena nekoga srednjovjekovnog bosansko-humskog vladara i velmože (po 11\%). Na posljednjem

ove dvije općine ni u novijoj, u praksi korištenoj hodonimiji, nisu zastupljeni srednjovjekovni bosansko-humski vladari i velmože.

8 Dijana Korać - Marina Beus, "Komemoriranje srednjovjekovnih hrvatskih vladara u hodonimima Hercegovine", u: Hercegovina, 6, Mostar - Zagreb, 2020., str. 383-399.

9 Izuzetak čini općina Grude, te kako je već naglašeno, općina Prozor-Rama i općina Ravno.

10 Službeni glasnik opštine Trebinje, 4, Trebinje, 1994., str. 56 (ćir.).

11 https://mapeulica.com/mapa-gacko-bih-3200768 (9. 10. 2020.). 
mjestu nalaze se Čapljina (ulica i trg), te Ljubuški, ${ }^{12}$ Stolac i Neum s dvije ulice (ili po $7 \%$ od ukupna broja).

Tabela 1. Zastupljenost ulica i trgova s imenima srednjovjekovnih bosansko-humskih vladara i velmoža po gradovima i općinama

\begin{tabular}{|l|l|l|}
\hline Grad/općina & $\begin{array}{l}\text { Ukupan } \\
\text { broj }\end{array}$ & Ime vladara/velmože \\
\hline Posušje & 8 & $\begin{array}{l}\text { Kulin, Tvrtko I., Matej Ninoslav, Hrvoje Vuk- } \\
\text { čić Hrvatinić, Stjepan Ostoja, Stjepan Vukčić } \\
\text { Kosača, Stjepan Tomašević, Katarina Kosača } \\
\text { Kotromanić }\end{array}$ \\
\hline Široki Brijeg & 6 & $\begin{array}{l}\text { Tvrtko I., Viganj Milošević, Hrvoje Vukčić } \\
\text { Hrvatinić, Stjepan Vukčić Kosača, Katarina } \\
\text { Kosača Kotromanić, knez Vladimirović }\end{array}$ \\
\hline Mostar & 3 & $\begin{array}{l}\text { Mihajlo Višević, Tvrtko I., Katarina Kosača } \\
\text { Kotromanić }\end{array}$ \\
\hline Čitluk & 3 & Tvrtko I., Katarina Kosača Kotromanić \\
\hline Čapljina & 2 & $\begin{array}{l}\text { Stjepan Tomašević, Katarina Kosača Kotro- } \\
\text { manić }\end{array}$ \\
\hline Ljubuški & 2 & $\begin{array}{l}\text { Stjepan Vukčić Kosača, Katarina Kosača } \\
\text { Kotromanić }\end{array}$ \\
\hline Stolac & 2 & Mihajlo Višević, Katarina Kosača Kotromanić \\
\hline Neum & 2 & Mihajlo Višević, Katarina Kosača Kotromanić \\
\hline
\end{tabular}

$12 \mathrm{U}$ radu se razmatra ulična nomenklatura u Ljubuškom na temelju posljednjih odluka o imenovanju ulica i trgova. Službeni glasnik općine Ljubuški, Ljubuški, 1/2016.; Službeni glasnik općine Ljubuški, Ljubuški, 7/2017., str. 322-325. No zanimljivo je spomenuti da su do 2016. godine u Ljubuškom postojali Trg bana Kulina i Trg kralja Tvrtka. 
Dijana Korać - Marina Beus - Srednjovjekovni bosansko-humski vladari i velmože...

Grafikon 1. Zastupljenost ulica i trgova s nazivima srednjovjekovnih bosansko-humskih vladara i velmoža po gradovima i općinama

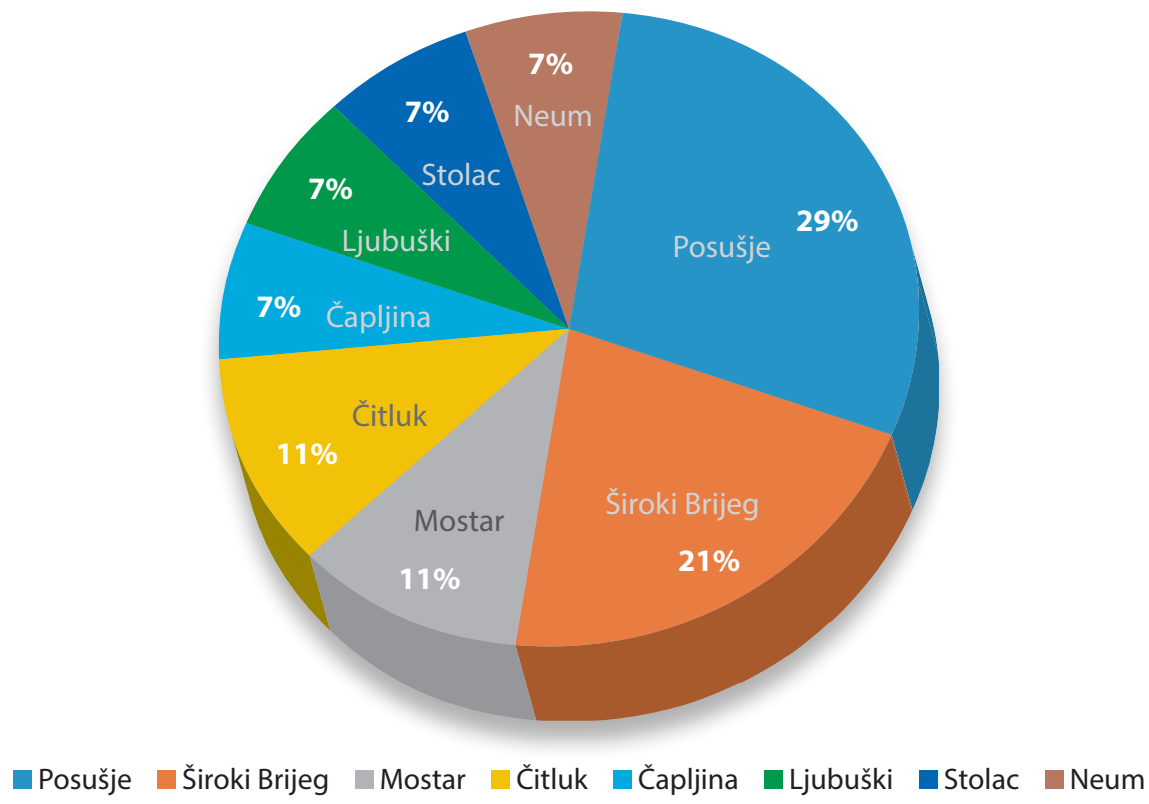

Analiza distribucije pojedinoga bosansko-humskog vladara i velmože u uličnoj onomastici na području Hercegovačko-neretvanske i Zapadno-hercegovačke županije dala je sljedeće rezultate. Na prvome mjestu nalazi se kraljica Katarina Kosača Kotromanić (1425.?-1478.) koju u nazivlju ulica i trgova komemorira ukupno osam hercegovačkih gradova i općina (njezino ime nosi jedan trg i osam ulica), ${ }^{13}$ što čini $32 \%$ od ukupno zabilježenih ulica i trgova koji nose imena po srednjovjekovnim bosansko-humskim vladarima i velmožama. Zanimljivo je da u ovim hodonimima nalazimo samo jedan trg ( $\mathrm{u}$ Čapljini), a on je posvećen upravo ovoj kraljici, što govori o recepciji kraljice Katarine na ovome prostoru. Budući da je ova kraljica zasigurno najomiljenija osoba iz srednjovjekovne bosansko-humske povijesti, njezino istaknuto mjesto u kolektivnom sjećanju Hrvata u Hercegovini osim trga potvrđuje i broj ulica (u osam navedenih

13 Napominjemo da se u općini Čitluk nalaze dvije ulice posvećene ovoj kraljici - jedna u Ćitluku a druga u Bijakovićima. 
gradova i općina). Kraljica Katarina, žena kralja Stjepana Tomaša, iako pretposljednja, u tradiciji je ostala kao posljednja bosanska kraljica, posebno mjesto u kolektivnom sjećanju Hrvata u Hercegovini vjerojatno je dobila zbog tragične sudbine koju je doživjela prilikom osmanlijskoga osvajanja Bosanskoga kraljevstva kada su u ropstvo odvedena njezina malodobna djeca Sigismund i Katarina, za koje se borila sve do posljednjega dana svoga života koji je skončala u Rimu 1478. godine. Poznata je njezina oporučna želja, da Bosansko kraljevstvo, ukoliko se nijedno od njezine djece ne vrati na katoličku vjeru, ostavlja Svetoj Stolici. ${ }^{14}$ Sve je ovo zasigurno utjecalo na njezino mjesto u hrvatskoj nacionalnoj povijesti, pa slijedom toga i u uličnoj onomastici Hercegovine.

Na drugome mjestu nalazi se kralj Stjepan Tvrtko I. (1353.-1391.) čije ime komemoriraju ulice u Posušju, Śrokom Brijegu, Mostaru i Čitluku (14\% od ukupna broja ovih hodonima). Ćinjenice da se radi o prvome bosanskome kralju okrunjenu 1377. godine najvjerojatnije u Milama kod Visokoga, koji je bio najmoćniji bosanski vladar o čemu svjedoči, između ostaloga, i njegov naslov "kralj Raške, Bosne, Dalmacije, Hrvatske i Primorja", zasigurno su razlozi zbog kojih je našao svoje mjesto u toponimiji Hercegovine. Također, valja kazati

14 Interes za istraživanjem života kraljice Katarine ne jenjava već desetljećima. Povodom 500. obljetnice njezine smrti u Sarajevu je održan povijesno-teološki simpozij. O tome: JosıP Turčınović (ur.), Katarina Kotromanić Kosača (1478-1978). Povijesno-teološki simpozij u povodu 500. obljetnice smrti bosanske kraljice Katarine, Sarajevo, 1979. Pregled literature do 2003. godine može se vidjeti u: EsAD KurTović, "Prilog bibliografiji radova o bosanskoj kraljici Katarini Kotromanić (1425-1478). U povodu 580. obljetnice rođenja i 525. obljetnice smrti)", u: Bosna franciscana, 22, Sarajevo, 2005., str. 201-211. U novije vrijeme također je objavljeno nekoliko radova koji se dotiču života ove kraljice. Krešımir Regan, Bosanska kraljica Katarina. Pola stoljeća Bosne (1425-1478), Zagreb, 2010.; Emir O. Filipović, "Was Bosnian Queen Catherine a member of the Third of St. Francis?", u: Radovi - Zavod za hrvatsku povijest Filozofskoga fakulteta Sveučilišta u Zagrebu, Zagreb, 1/2015., str. 165-182; Dijana Korać, "Neki aspekti religioznosti u Kosača", u: Croatica Christiana periodica, 72, Zagreb, 2013., str. 51-72; Dijana Korać, Religioznost humske vlastele u kasnom srednjem vijeku, Mostar, 2016.; LukA ŠPOLJARIć, "Bosanska kraljica Katarina i humanisti, dio prvi: Leonardo Montagna i njegovi epigrami", u: Zbornik Odsjeka za povijesne znanosti Zavoda za povijesne i društvene znanosti Hrvatske akademije znanosti i umjetnosti, 36, Zagreb, 2018., str. 61-80; Luka ŠPoljarić, "Bosanska kraljica Katarina i humanisti, dio drugi: Nikola Modruški, De humilitate", u: Zbornik Odsjeka za povijesne znanosti Zavoda za povijesne i društvene znanosti Hrvatske akademije znanosti $i$ umjetnosti, 37, Zagreb, 2019., str. 83-97. 
i da je nakon smrti Ludovika Velikog pod svoju vlast vratio zapadni dio Humske zemlje. ${ }^{15}$ Osim toga, općina Čitluk, za njegovo komemoriranje ima još jedan dodatan razlog. Naime, nakon što je naslijedio strica Stjepana II. Kotromanića, Tvrtko je kao mladi bosanski ban, prilikom prvoga posjeta Humskoj zemlji boravio u Brotnju gdje je 1353./1354. godine izdao ispravu Vlatku Vukoslaviću Hrvatiniću i njegovim potomcima. Ova ćirilska isprava pisana je na lokalitetu Suha na Prozračcu a u njoj se spominje i vino (po kojemu je ovaj kraj i danas poznat). ${ }^{16}$

15 Unatoč isticanju njegove slavne vladavine u srednjovjekovnoj bosansko-humskoj povijesti historiografija o Tvrtku I. Kotromaniću nije bogata. Naime, dok su neki segmenti njegova života (npr. krunidba i isprave) predmet interesa brojnih povjesničara, monografija o ovome vladaru nije napisana još od 1925. godine. Vladimir Ćorović, Kralj Tvrtko I Kotromanić, Beograd, 1925. (ćir.). O Tvrtku I. s uputom na ostalu literaturu: Minailo Dinıć, "O krunisanju Tvrtka I za kralja", u: Glas Srpske kraljevske akademije, CXLVII., Beograd, 1932., str. 135-145 (ćir.); Sima Ćirković, "Sugubi venac (prilog istoriji kraljevstva u Bosni)", u: Zbornik Filozofskoga fakulteta, VIII., Beograd, 1964., str. 343-370 (ćir.); Đuro BASLER, "Proglašenje Bosne kraljevinom 1377. godine", u: Prilozi, 11-12, Sarajevo, 1975./1976., str. 49-61 (ćir.); Dubravko Lovrenović, "Proglašenje Bosne kraljevstvom 1377. (pokušaj revalorizacije)", u: Forum Bosnae, 3-4, Sarajevo, 1999., str. 227-287; Dubravko Lovrenović, Bosanska kvadratura kruga, Sarajevo - Zagreb, 2012., str. 329-368; DžEnAn Dautović - Enes Dedić, "Povelja kralja Tvrtka I Kotromanića Dubrovniku (Žrnovnice, 10. april 1378 - Trstivnica, 17. juni 1378)", u: Godišnjak/Jahrbuch, 45, Sarajevo, 2016., str. 225-246. U novije vrijeme izišao je i zbornik radova u kojemu se mogu naći radovi koji se bave ispravom bana Tvrtka I. iz 1366. godine izdanoj Hrvoju Vukčiću Hrvatiniću ali i drugi radovi koji govore o srednjovjekovnoj Bosni i Humu. O tome: Tomislav Brković (ur.), Bosanski ban Turtko "pod Prozorom u Rami". Zbornik radova s međunarodnoga znanstvenog skupa održanog u Prozoru 11. kolovoza 2016., Prozor - Sarajevo - Zagreb, 2016.

16 Usp. Marko Vego, Brotnjo od najstarijih vremena do 1878. godine, Čitluk, 1981., str. 85; Ante ŠKegro, "Brotnjom od pretpovijesti do srednjega vijeka", u: Dario Dodig - Dijana Korać (prir.), Župa Čerin. 150. obljetnica osnutka župe (1864.-2014.), Tomislavgrad - Čerin, 2014., str. 23; Dijana Korać, "Područje Brotnja (Broćna) u srednjem vijeku", u: DARIo Dodig - Dijana Korać (prir.), Župa Čerin. 150. obljetnica osnutka župe (1864.-2014.), Tomislavgrad Čerin, 2014., str. 46; Dijana Korać, "Neka pitanja iz srednjovjekovne povijesti Brotnja. Rezultati i problemi dosadašnjih istraživanja", u: Motrišta, 83-84, Mostar, 2015., str. 79-93. Na kraju navedene isprave piše: "A sie (ovo) se svr'ši na Suhoi na Prozračcu k'da (kada) g(ospo)d(i)n ban' Tvr'tko gred še(gredijaše) naipr'vo u Hl'msku zemlu. A se (ovo) pisa Dražeslav' dijak' g(ospo)d(i)na bana Tvr'tka nadvorni pis'c (pisar), a pr'vo dijak Velikoslav'noga g(ospo)d(i)na bana Stipana (Stjepana II. Kotromanića). I k'da (kada) sie (ovo) pisah' t'da (tada) mi da (dade) g(ospo)d(i)n' ban' Tvr'tko ispred' sebe velik' pehar' vina popiti u 
Treće mjesto po učestalosti pojavljivanja u hercegovačkim hodonimima dijele knez Mihajlo Višević i herceg Stjepan Vukčić Kosača kojima su posvećene po tri ulice u hercegovačkim gradovima i općinama (po 11\% od ukupna broja). Naime, Mihajlu Viševiću posvećene su ulice u Mostaru, Stocu i Neumu. Mihajlo Višević (oko 910.-930.) prvi poznati humski knez koji je sudjelovao na crkvenom saboru u Splitu 925. godine zajedno s kraljem Tomislavom, a kojega papa Ivan $\mathrm{X}$. u pismu, koje je poslao uoči navedenoga splitskog crkvenog sabora, naziva "izvrsnim knezom Humljana", ${ }^{17}$ također nije iznenađenje kao izbor prilikom (de)nominacije ulica.

Stjepan Vukčić Kosača (1404.?-1466.), uza svoju kći Katarinu, zasigurno je u Hercegovini jedna od najpoznatijih osoba iz srednjovjekovne bosansko-humske povijesti. Uspomenu na ovoga bosanskohumskoga velmožu komemoriraju ulice u Širokom Brijegu, Posušju i Ljubuškom. Nakon što je 1435. godine naslijedio svoga strica Sandalja Hranića, Stjepan je proširio vlast Kosača, a vlast mu se protezala od Lima do Cetine i od Rame do Kotorskoga zaljeva. "Hercegom od sv. Save" proglasio se 1448. godine čime je iskazao svoju težnju za samostalnošću. ${ }^{18}$ Činjenica da je prostor koji je bio pod njegovom vla-

dobru volu (volju)." Prijepis isprave vidjeti u: Marko Vego, Postanak srednjovjekovne bosanske države, Sarajevo, 1982., str. 154-155.

17 O Mihajlu Viševiću vidi primjerice: Skupina Autora, Povijest Bosne i Hercegovine od najstarijih vremena do godine 1463., Sarajevo, ${ }^{3} 1998 .$, str. 176, 188 192; Tomislav Raukar, Hrvatsko srednjovjekovlje, prostor, ljudi, ideje, Zagreb, 1998., str. 37-38, 303, 305-306; Milko BRKović, Srednjovjekovna Bosna i Hum. Identitet $i$ kontinuitet, Mostar, ${ }^{2} 2010$., str. 26-27, 100; Franjo ŠANJEK (ur.), Povijest Hrvata, knj. 1, Srednji vijek, Zagreb, 2003., str. 91, 145, 293.

18 Stjepan Vukčić Kosača već je desetljećima predmet interesa mnogih povjesničara o čemu svjedoče brojni radovi, od kojih ćemo ovdje navesti samo neke. Mihailo Dinić, Zemlje Hercega Svetoga Save, Beograd, 1940. (ćir.); Bare Poparić, Tužna povijest hercegove zemlje 1437.-1482., Zagreb, 1942.; Sima M. Ćirković, Herceg Stefan Vukčić-Kosača i njegovo doba, Beograd, 1964. (ćir.); Marko Vego, "Tri povelje o posjedima Stjepana Vukčića Kosače", u: Most, 19-20, Mostar, 1978., str. 123-142; MAR Ko VEGo, "Prilog poznavanju srednjovjekovnih gradova hercega Stjepana Vukčića Kosače", u: Most, 28-29, Mostar, 1980., str. 129-140; MARIJAN Sivrić, "Oporuka i smrt hercega Stjepana Vukčića Kosače", u: Motrišta, 18, Mostar, 2000., str. 78-84; Emir O. Filipović, "Povelja hercega Stjepana Vukčića Kosače Barbari od Liechtensteina, 1. mart 1455. godine", u: Građa arhiva Bosne i Hercegovine, 5, Sarajevo, 2013., str. 7-19; D. Korać, "Neki aspekti religioznosti u Kosača", str. 51-72. U novije vrijeme Kosače su bili tema više znanstvenih skupova u Hercegovini, a radovi su objavljeni u sljedećim zbornicima. RADoslav BRATIĆ (prir.), Kosače - osnivači 
Dijana Korać - Marina Beus - Srednjovjekovni bosansko-humski vladari i velmože...

šću nazvan Hercegovina (po njegovoj tituli) zasigurno je presudila u komemoriranju njegova imena u hercegovačkim hodonimima.

Po dvije ulice u Hercegovini (po 7\% od ukupna broja) nose imena vojvode Hrvoja Vukčića Hrvatinića i kralja Stjepana Tomaševića. Uspomenu na Hrvoja Vukčića Hrvatinića (oko 1350.-1416.), čuvaju ulice u Posušju i Širokom Brijegu. Hrvoje je najpoznatiji član jedne od najmoćnijih velikaških obitelji srednjovjekovne Bosne. Bosanski kralj Tvrtko I. dodijelio mu je titulu velikoga bosanskog vojvode, a nakon što je podržao Ladislava Napuljskog postaje i splitski herceg te mu je 1391. godine na upravu povjerena Dalmacija i Hrvatska. Nosio je titulu "herceg Splita, potkralj Dalmacije i Hrvatske, veliki vojvoda bosanski i knez Donjih kraja". Bio je jedna od najutjecajnijih osoba u srednjovjekovnome Bosanskom kraljevstvu a za pomoć su mu se obraćali i Dubrovčani koji su mu predlagali i da se okruni za bosanskoga kralja. O njegovoj moći govore i činjenice da je kao splitski herceg kovao svoj novac, a po njegovoj narudžbi nastali su Hrvojev misal i Hvalov zbornik. ${ }^{19}$ Spomenimo i da je njegov nećak Juraj Vojsalić ispravom iz 1434. godine braći Jurjevićima potvrdio ranije posjede te vratio ono što im je Sandalj oduzeo. ${ }^{20}$ Sve su to, po svemu sudeći, razlozi zbog kojih je Hrvoje Vukčić Hrvatinić našao svoje mjesto u uličnoj nomenklaturi Hercegovine.

Ulice kralja Stjepana Tomaševića (1461.-1463.) nalaze se u Posušju i Čapljini. Razlozi njegova komemoriranja u ovim ulicama vjerojatno leže u činjenici da je Stjepan Tomašević bio posljednji bosanski kralj, koji je nakon samo dvije godine vladanja doživio slom Bosanskoga kraljevstva te njegove tragične sudbine (Osmanlije su ga pogubili u Jajcu). ${ }^{21}$

Hercegovine, Bileća - Gacko - Beograd, 2002.; Munib Maglajlić (ur.), Herceg Stjepan Vukčić Kosača i njegovo doba, Mostar, 2003. Također, na Filozofskom fakultetu Sveučilišta u Mostaru održan je međunarodni znanstveni skup Povijesno nasljeđe hercega Stjepana Vukčića Kosače - 550 godina od smrti (1466.2016.), a radovi su objavljeni u časopisu Hercegovina, 3, Mostar, 2017.

19 O Hrvoju Vukčiću Hrvatiniću više: Ferdo ŠIšić, Hrvoje Vukčić Hrvatinić $i$ njegovo doba (1350.-1416.), Zagreb, ${ }^{2} 2004$.; Milko Brković, Hrvoje Vukčić Hrvatinić (1380.-1416.) u zrcalu vlastitih isprava, Sarajevo, 2008.

20 Navedena isprava tiskana je u: Franz Miklosich, Monumenta Serbica spectantia historiam Serbiae Bosnae Ragusii, Viennae, 1858., str. 377-379; M. VEGO, Postanak srednjovjekovne bosanske države, str. 181-183. O značenju isprave i okolnostima njezina nastanka: MLaden Ančić, Na rubu Zapada: tri stoljeća srednjovjekovne Bosne, Zagreb, 2001., str. 76-77.

21 O Stjepanu Tomaševiću više: Skupina autora, Povijest Bosne i Hercegovine od najstarijih vremena do godine 1463., str. 555-587. O kralju Stjepanu To- 
Na kraju, uspomenu na bana Kulina, bana Mateja Ninoslava, kralja Stjepana Ostoju, Vignja Miloševića te kneza Vladimirovića komemorira po jedna ulica u Hercegovini (po 3,6\% od ukupna broja). Naime, uspomenu na bana Kulina, bana Mateja Ninoslava i kralja Stjepana Ostoju čuvaju ulice u Posušju. Slavnoga bana Kulina (1180.1204.), kojega papinski legat Teobald u jednome pismu iz 1180. godine naziva "velikim banom", narodna predaja pamti kao najboljega bosanskog vladara ( $Z a$ Kulina bana dobrijeh dana). Iako ga je dukljanski knez Vukan optužio za herezu, Kulin je cijeli svoj život ostao u dobrim odnosima s Rimom. Kao vladar čvrsto je stajao uz Crkvu i bio u dobrim odnosima s Dubrovčanima s kojima je 1189. godine sklopio prvi poznati trgovački ugovor kojim dubrovačkim trgovcima dopušta slobodno kretanje po svojoj zemlji. ${ }^{22}$ Zbog svega navedenog, mogao se činiti kao "logičan" izbor prilikom (de)nominacije ulica u Hercegovini.

Ban Matej Ninoslav (1233.-1250.) je možda najveće iznenađenje u ovim hodonimima. Naime, u historiografiji se apostrofira njegov dobar odnos s pripadnicima Crkve bosanske zbog čega ga neki autori smatraju "heretikom", dok ga drugi autori, s obzirom na neke isprave koje govore o njegovu odnosu s Rimom, smatraju vjernim katolikom. Također, "veliki bosanski ban po milosti Božjoj", Matej Ninoslav, 1240. godine izdaje Dubrovčanima ispravu o vječnom miru i prijateljstvu. ${ }^{23}$

maševiću u novije vrijeme objavljeni su vrijedni radovi u: Ante BIRIN (ur.), Stjepan Tomašević (1461.-1463.) - slom srednjovjekovnoga Bosanskog Kraljevstva. Zbornik radova sa Znanstvenoga skupa održanog 11. i 12. studenoga 2011. godine u Jajcu, Zagreb, 2013.

22 O banu Kulinu: Skupina autora, Povijest Bosne i Hercegovine od najstarijih vremena do godine 1463., str. 204-216; F. ŠAnJEK (ur.), Povijest Hrvata, knj. 1, Srednji vijek, str. 234, 420-421; M. BRKović, Srednjovjekovna Bosna i Hum. Identitet $i$ kontinuitet, str. 42-48. Ban Kulin, a posebno njegova povelja Dubrovniku iz 1189. godine, više od sto godina predmet je interesa različitih znanstvenih istraživanja. U novije vrijeme izišao je zbornik radova: Asım Peco (ur.), Osamsto godina povelje bosanskoga bana Kulina 1189-1989, Sarajevo, 1989. U istome djelu izišao je članak u kojemu se može naći bibliografija radova. Nevenka Gošıć, "Bibliografija", u: Asım Peco (ur.), Osamsto godina povelje bosanskoga bana Kulina 1189-1989, Sarajevo, 1989., str. 105-123. Prva monografija o banu Kulinu objavljena je prije dvije godine, a iz tiska je izišla nekoliko mjeseci nakon smrti njezina autora. Salih Jalimam, Kulin, veliki ban Bosne, Zenica, 2019.

23 Ova isprava tiskana je u: Fr. Miklosich, Monumenta Serbica spectantia historiam Serbiae Bosnae Ragusi, Viennae, 1858., str. 28-29; Ljubomir STojAnović, Stare srpske povelje i pisma, knj. I/1, Beograd - Sremski Karlovci, 1929., str. 7-9; 
Stjepan Ostoja, bosanski kralj od 1398. do 1404. i od 1409. do 1418. zasigurno je svoje mjesto u ovim hodonimima našao zbog sačuvanih isprava u kojima se spominje ovo područje. Naime, ovaj je kralj u Posušju 1403. godine primio dubrovačke poslanike. Također, Posušje se spominje i u njegovoj ispravi iz 1408. godine kojom braći Radivojevićima potvrđuje posjede koje su imali u Dalmaciji i Humskoj zemlji. ${ }^{24}$

Na kraju, po jedna ulica u Širokom Brijegu nosi ime Vignja (Miloševića) te kneza Vladimirovića što nije iznenađenje u širokobriješkim hodonimima s obzirom da je riječ o osobama koje su ostavile traga u srednjovjekovnoj povijesti ovoga kraja. Viganj Milošević je zasigurno danas vrlo poznat u širokobriješkome kraju. Naime, njegov nadgrobni spomenik pronađen je na nekropoli Lipovci nedaleko od Kočerina, a ploča s natpisom datiranim 1404. godinom ugrađena je u vanjski zid župnoga stana u Kočerinu. Kočerinska ploča, odnosno natpis Vignja Miloševića, predstavlja vrijedan spomenik na kojemu se nalaze imena više bosanskih vladara (ban Stjepan II. Kotromanić, kralj Tvrtko I., kralj Stjepan Dabiša, kraljica Jelena Gruba i kralj Stjepan Ostoja) kojima je Viganj za svoga života služio. ${ }^{25}$

Iako u samome nazivu ulice nije precizirano o kojemu je knezu Vladimiroviću točno riječ, prema dopisu koji smo dobili od mjerodavne institucije, postoji mogućnost da se radi o jednome od sljedećih knezova - Grgur, Radoslav i Vladimir. ${ }^{26}$ Naime, Vladimirovići su imali svoje

MiLko Brкović, Diplomatički zbornik srednjovjekovnih humskih i bosanskih isprava Dubrovniku, Mostar, 2011., str. 28-29. O Mateju Ninoslavu više: SKUPINA AUTORA, Povijest Bosne i Hercegovine od najstarijih vremena do godine 1463., str. 219-231; F. ŠAnJEK (ur.), Povijest Hrvata, knj. 1, Srednji vijek, str. 235; M. BRKović, Srednjovjekovna Bosna i Hum. Identitet $i$ kontinuitet, str. 48-49, 135-142.

24 Usp. Marko Vego, Naselja bosanske srednjevjekovne države, Sarajevo, 1957., str. 95. Navedene isprave tiskane su u: NicolaE Jorga, Notes et extraits pour servir a l'histoire des croisades au XV siecle, sv. II., Paris, 1899., str. 90; EUSEBIus FermendžIn, Acta Bosnae potissimum ecclesiastica cum insertis editorum documentorum regestis ab anno 925 usque ad annum 1752., Zagrabiae, 1892., str. 87-89. O kralju Stjepanu Ostoji više: Skupina Autora, Povijest Bosne i Hercegovine od najstarijih vremena do godine 1463., str. 374-412, 427-451; F. ŠAnjeK (ur.), Povijest Hrvata, knj. 1, Srednji vijek, str. 379-381; M. BRKović, Srednjovjekovna Bosna i Hum. Identitet i kontinuitet, str. 64-65, 67-72.

25 Kočerinska ploča i prilike u kojima je živio Viganj Milošević bili su tema znanstvenoga skupa, a radovi su objavljeni u zborniku radova: Grgo MikuLIĆ (ur.), Viganj i njegovo doba, Široki Brijeg, 2004.

26 Kako u samome nazivu ulice nije precizirano o kojem je knezu riječ, tražili smo od mjerodavne institucije pojašnjenje, ali nismo dobili konkretan odgovor. Na- 
sjedište na području srednjovjekovne župe Blato (današnje selo Uzarići), a nakon što su Bosna i Hum potpali pod osmansku vlast odseljavaju u Dalmaciju. U srednjovjekovnim ispravama spominje se nekoliko knezova ove obitelji koji se navode kao suci ili pak svjedoci u ispravama više bosansko-humskih vladara, ${ }^{27}$ pa s obzirom na sve navedeno, mišljenja smo da bi bilo "ispravnije" ulicu zvati knezova Vladimirovića.

Tabela 2. Učestalost pojavljivanja bosansko-humskih vladara i velmoža po gradovima i općinama

\begin{tabular}{|l|l|l|}
\hline Ime & $\begin{array}{l}\text { Broj ulica } \\
\text { i trgova }\end{array}$ & Grad/općina \\
\hline Katarina Kosača Kotromanić & $8+1$ & $\begin{array}{l}\text { Posušje, Čitluk, Bijakovi- } \\
\text { ći - Čitluk, Čapljina (trg), } \\
\text { Široki Brijeg, Ljubuški, } \\
\text { Stolac, Neum, Mostar }\end{array}$ \\
\hline Tvrtko I. & 4 & $\begin{array}{l}\text { Posušje, Čitluk, Široki } \\
\text { Brijeg, Mostar }\end{array}$ \\
\hline Stjepan Vukčić Kosača & 3 & $\begin{array}{l}\text { Posušje, Široki Brijeg, } \\
\text { Ljubuški }\end{array}$ \\
\hline Mihajlo Višević & 3 & Stolac, Neum, Mostar \\
\hline Stjepan Tomašević & 2 & Posušje, Čapljina \\
\hline Hrvoje Vukčić Hrvatinić & 2 & Posušje, Široki Brijeg \\
\hline ban Kulin & 1 & Posušje \\
\hline Matej Ninoslav & 1 & Posušje \\
\hline Stjepan Ostoja & 1 & Posušje \\
\hline Viganj Milošević & 1 & Široki Brijeg \\
\hline knez Vladimirović & 1 & Široki Brijeg \\
\hline
\end{tabular}

ime, u arhivu među dokumentima sa sjednice na kojoj je usvojena Odluka o obilježavanju ulica i trgova imenima i zgrada brojevima nije sačuvano obrazloženje iz kojega bi bilo evidentno na kojega kneza Vladimirovića Širokobriježani žele sačuvati uspomenu. Dostavljen nam je dopis jednoga člana Povjerenstva za izradu spomenute Odluke, a zapravo se radi o dijelu knjige s naslovom Podrijetlo hrvatskih starosjedilačkih rodova u Širokom Brijegu i okolici, autora Nikole Mandića, gdje se spominju tri kneza Vladimirovića - Grgur, Radoslav i Vladimir, što upućuje na zaključak da se ipak naziv ulice trebao odnositi na knezove Vladimiroviće. O tome: Nikola Mandić, Podrijetlo hrvatskih starosjedilačkih rodova u Širokom Brijegu i okolici, Široki Brijeg, 2002., str. 58-59.

27 Usp. Skupina Autora, Povijest Bosne i Hercegovine od najstarijih vremena do godine 1463., str. 455, 484, 558-559; Enver LJuBović, "Bunjevačka plemićka i časnička obitelj Rukavina", u: Senjski zbornik: prilozi za geografiju, etnologiju, gospodarstvo, povijest i kulturu, 31, Senj, 2004., str. 39-41. 
Dijana Korać - Marina Beus - Srednjovjekovni bosansko-humski vladari i velmože...

Grafikon 2. Učestalost pojavljivanja bosansko-humskih vladara i velmoža u hodonimima Hercegovine

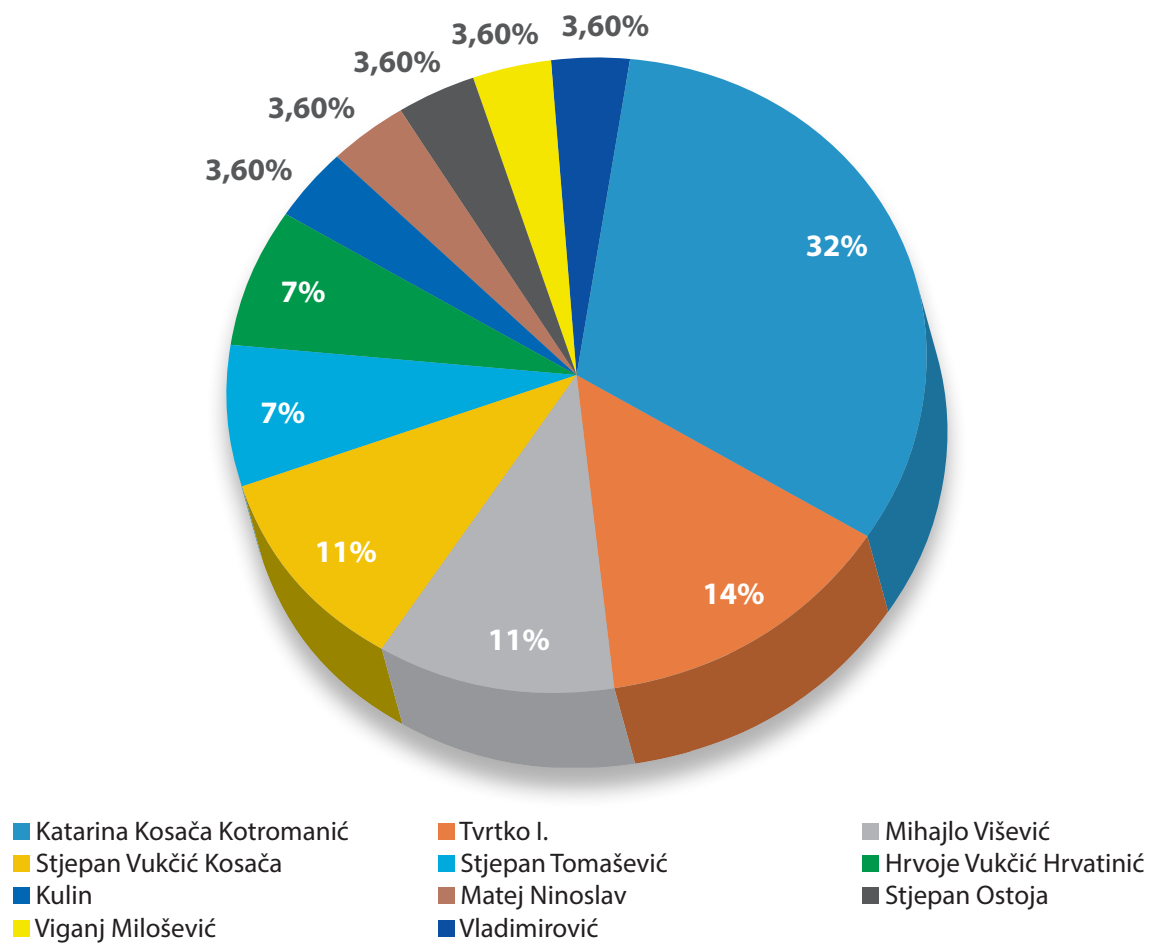

Potvrđena je početna hipoteza da su u hercegovačkim hodonimima srednjovjekovni hrvatski vladari zastupljeniji od srednjovjekovnih bosansko-humskih vladara i velmoža. Naime, u uličnoj toponimiji deset hercegovačkih gradova i općina (Mostar, Čapljina, Široki Brijeg, Ljubuški, Čitluk, Stolac, Neum, Grude, Posušje i Prozor-Rama) evidentna je zastupljenost 14 srednjovjekovnih hrvatskih vladara čija imena nose ukupno 46 ulica i jedan trg. S druge strane u osam hercegovačkih gradova i općina (Mostar, Posušje, Čapljina, Široki Brijeg, Ljubuški, Čitluk, Stolac, Neum,) evidentiran je jedan trg i 27 ulica koji komemoriraju uspomenu na 11 srednjovjekovnih bosanskohumskih vladara i velmoža.

Sličnost se očituje u geografskoj distribuciji. Naime, na prvome i drugome mjestu po broju imenovanih ulica po srednjovjekovnim 
hrvatskim vladarima te bosansko-humskim vladarima i velmožama u uličnoj nomenklaturi Hercegovine nalaze se Posušje i Široki Brijeg, u kojima je pak znatno veći broj hodonima koji komemoriraju uspomenu na nekoga od srednjovjekovnih hrvatskih vladara. Dok se u općinama Ljubuški, Stolac i Neum nalazi podjednak broj ovih hodonima, u Mostaru, Čapljini i Čitluku nalazi se manji broj hodonima koji nose ime bosansko-humskih vladara i velmoža od onih koji komemoriraju uspomenu na nekoga od srednjovjekovnih hrvatskih vladara.

\section{Zaključak}

Slom jugoslavensko-komunističke vlasti 90 -ih godina prošloga stoljeća i na hercegovačkom prostoru rezultirao je, između ostaloga, izmjenom i u uličnoj nomenklaturi. Kako je riječ o prostoru s većinskim hrvatskim stanovništvom, te činjenici da vlast na lokalnoj razini obnašaju pripadnici hrvatskih nacionalnih stranaka, isticana su nacionalna obilježja pa slijedom toga birana su i imena ulica i trgova. Ovaj postupak nije iznimka, nego gotovo uobičajeno pravilo, što ne iznenađuje ako se ima u vidu da ulična onomastika svjedoči kako o jezičnim, kulturnim, civilizacijskim, tako i povijesnim i ideološkim odrednicama nekoga prostora, pa stoga političke elite proces pre/ imenovanja ulica koriste kao neizravni mehanizam u oblikovanju ne samo identiteta naselja nego i svjetonazora stanovnika.

Analiza uličnoga nazivlja u hercegovačkim županijama pokazala je kako su srednjovjekovni bosansko-humski vladari i velmože zastupljeni u osam hercegovačkih gradova i općina s većinskim hrvatskim stanovništvom. Njihovo komemoriranje u uličnoj nomenklaturi Hercegovine upućuje na zaključak kako su predlagači nazivlja ulica i trgova, poticanjem s jedne strane kolektivnoga zaborava u odnosu na prošlu zbilju (u ovom slučaju na jugoslavensko razdoblje), a s druge strane promicanjem kulture sjećanja, između ostaloga, i na srednjovjekovne bosansko-humske vladare i velmože, imali cilj i jačanje kolektivnog identiteta hrvatskoga naroda na ovome prostoru.

Usporedbom dobivenih podataka s rezultatima istraživanja koji se odnose na prisutnost srednjovjekovnih hrvatskih vladara u hodonimima Hercegovine došlo se do zaključka da su srednjovjekovni hrvatski vladari znatno zastupljeniji od bosansko-humskih vladara i velmoža u hercegovačkoj toponimiji. 
Dijana Korać - Marina Beus - Srednjovjekovni bosansko-humski vladari i velmože...

Ovakav omjer navedenih hodonima može se smatrati očekivanim s obzirom na vrijeme (de)nominacije ulične nomenklature kada su službene vlasti, imajući u vidu određene povijesne osobe ili pak događaje iz hrvatske srednjovjekovne povijesti, nastojali utjecati na jačanje hrvatske nacionalne svijesti i kolektivnog identiteta. To možda najbolje pokazuje primjer komemoriranja prvoga hrvatskoga kralja Tomislava koji je na prvome mjestu (11 hodonima u Hercegovini nosi njegovo ime) od svih srednjovjekovnih osoba na koje se čuva uspomena u hercegovačkim hodonimima. 